\title{
SERTIFIKASI HALAL SEBAGAI PENERAPAN ETIKA BISNIS ISLAMI DALAM UPAYA PERLINDUNGAN BAGI KONSUMEN MUSLIM
}

\author{
Ramlan \\ Fakultas Hukum Universitas Muhammadiyah Sumut \\ Jl. Muchtar Basri No. 3 Medan \\ E-mail: ramlan_mosya71@yahoo.com \\ Nahrowi \\ Fakultas Syariah dan Hukum UIN Syarif Hidayatullah Jakarta \\ Jl. Ir. H. Juanda No. 95, Ciputat, Jakarta Selatan \\ E-mail: nahrowi73@yahoo.com
}

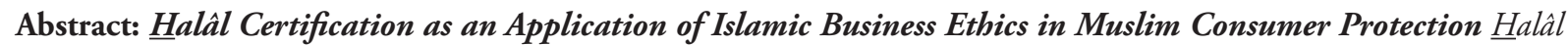
certification in food is needed by Muslim consumers to provide assurances that they are not consuming or using product or service that are not halâl so that no sin is commited. It is the duty of government to provide assurances to Muslim consumers that consumer goods or services that are circulating amongst society are really $\underline{h}$ alâl. The $\underline{h}$ alâl label itself provides benefits to businesses such as improving consumer confidence to consume, reaching the global $\underline{\underline{h}}$ alâl food market, increasing the marketability of products in market and low cost investment. Muslim consumers also have to be smart before purchasing product or services for security and safety.
\end{abstract}

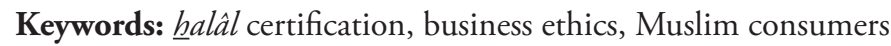

\begin{abstract}
Abstrak: Sertifikasi Halal sebagai Penerapan Etika Bisnis Islami dalam Upaya Perlindungan bagi Konsumen Muslim. Sertifikasi halal dalam makanan sangat dibutuhkan oleh konsumen Muslim untuk memberikan jaminan agar tidak mengkonsumsi atau menggunakan produk barang atau jasa yang tidak halal sehingga tidak terkena dosa. Maka menjadi tugas pemerintah untuk memberikan jaminan kepada konsumen Muslim agar produk barang atau jasa yang beredar di tengah-tengah masyarakat benar-benar halal. Label halal sendiri memberikan keuntungan bagi pelaku usaha seperti meningkatkan kepercayaan konsumen, meraih pasar pangan halal global, meningkatkan marketability produk di pasar dan investasi berbiaya murah. Konsumen Muslim harus cerdas sebelum membeli sebuah produk atau jasa demi keamanan dan keselamatan.
\end{abstract}

Kata Kunci: sertifikasi halal, etika bisnis, konsumen Muslim

\section{Pendahuluan}

Beberapa waktu lalu konsumen di Indonesia dihebohkan oleh temuan adanya bakso yang dibuat dari daging babi. Pernah juga terjadi beberapa kosmetik memiliki unsur dari hewani yang sifatnya haram. Mayoritas penduduk Indonesia yang beragama Islam merasa terkejut dan khawatir bahwa bakso dan kosmetik yang mereka konsumsi dan pakai selama ini berasal dari daging babi yang diharamkan. Hal itu dikarenakan saat ini ilmu pengetahuan dan teknologi pada bidang pangan, obat-obatan dan kosmetika mengalami perkembangan pesat yang luar biasa.

Pada masa lalu pengolahan dan pemanfaatan bahanbahan baku untuk pangan, obat-obatan dan kosmetika

Naskah diterima: 15 Juli 2013, direvisi: 20 September 2013, disetujui untuk terbit: 1 November 2013. sangat sederhana dan berasal dari bahan tumbuhtumbuhan. Akan tetapi seiring perkembangan waktu manusia menemukan teknologi yang ternyata dapat merekayasa apa yang terdapat pada alam sampai hal-hal yang sifatnya mikro sekalipun. Jika pada masa lalu untuk mengetahui sebuah produk halal bukan merupakan persoalan yang sulit karena bahan baku yang digunakan dapat diketahui secara jelas dan proses pembuatannya tidak terlalu rumit, maka berbeda halnya dengan apa yang terjadi hari ini.

Teraplikasinya perdagangan pangan yang jujur dan bertanggungjawab merupakan salah satu tujuan penting dari pengaturan, pembinaan dan pengawasan di bidang pangan seperti yang dikehendaki oleh UU No. 7 Tahun 1996 tentang Pangan. Banyaknya bahan makanan yang beredar di masyarakat tanpa memperhatikan 
pencantuman label halal sesungguhnya merupakan pelanggaran hak terhadap konsumen yang beragama Islam. Belum lagi pemakaian boraks, formalin, bahan pengawet dan pewarna pakaian yang dipakai dalam bahan pangan yang dapat mengakibatkan terganggunya kesehatan manusia.

Konsumen Muslim yang merupakan mayoritas penduduk di Indonesia adalah pihak yang paling dirugikan dengan banyaknya komoditas pangan tanpa label halal. Kepastian halal-tidaknya sebuah produk tentunya harus melalui mekanisme yang sesuai dengan ketentuan ajaran Islam. Majelis Ulama Indonesia (MUI) yang selama ini memiliki otoritas untuk memberikan sertifikasi halal bagi produsen yang memproduksi makanan halal paling tidak harus terus menelaah bahan baku sebuah produk yang terus berkembang.

Tulisan ini akan menelaah tentang urgensi sertifikasi halal sebagai bentuk perlindungan terhadap konsumen Muslim sebagai bagian dari penerapan etika bisnis dalam Islam.

\section{Tinjauan Umum tentang Sertifikasi Halal}

Seiring berkembangnya zaman, ilmu pengetahuan dan teknologi semakin berkembang termasuk cara pengolahan bahan pangan yang semakin variatif. Di pasaran dapat ditemukan beragam produk olahan dari pelbagai bahan dasar, baik yang diproduksi pabrik makanan lokal maupun impor dari perusahaan asing. Bahkan sekarang banyak pembuatan makanan olahan yang bersifat kompleks dan makanan tersebut dibuat dari pelbagai kandungan yang tidak semuanya jelas kehalalannya. ${ }^{1}$ Dalam Alquran surat al-Baqarah[2]: 168 dan al-Mâidah[3]: 88 Allah Swt jelas sekali memerintahkan umat Islam untuk mengkonsumsi makanan yang halal dan baik.

Sebagian masyarakat awam berpandangan bahwa makanan yang sehat dan baik sudah cukup untuk memenuhi kebutuhan dan asupan gizi. Padahal semua asupan yang sehat dan baik itu tidak akan menambah kesehatan dan kebaikan jika tidak dilengkapi dengan faktor halal. ${ }^{2}$

Sertifikat halal adalah fatwa tertulis Majelis Ulama Indonesia (MUI) yang menyatakan kehalalan suatu produk sesuai dengan syariat Islam. ${ }^{3}$ Sertifikat halal merupakan syarat untuk mencantumkan label halal.

\footnotetext{
${ }^{1}$ Hanif as Syifa, "Urgensi Sertifikasi Halal", dalam www.coreta hanifah.wordpress.com., diunduh tanggal 17 Maret 2013.

2 Hanif as Syifa, "Urgensi Sertifikasi Halal", dalam www. coretanhanifah.wordpress.com., diunduh tanggal 17 Maret 2013.

3 Departemen Agama Republik Indonesia, Panduan Sertifikasi Halal, (Jakarta: Departemen Agama RI, 2003I), h. 1.
}

Tujuan pelaksanaan sertifikasi halal pada produk pangan, obat-obatan dan kosmetika adalah untuk memberikan kepastian kehalalan suatu produk sehingga dapat menentramkan batin yang mengkonsumsinya. ${ }^{4}$

Sertifikat halal merupakan sertifikasi halal yang dikeluarkan oleh Lembaga Pengkajian Pangan, Obatobatan dan Kosmetika Majelis Ulama Indonesia (LPPOM-MUI) yang menyatakan suatu produk sudah sesuai dengan syariat Islam. ${ }^{5}$ Sertifikat halal ini dapat digunakan untuk pembuatan label halal.

Komitmen Majelis Ulama Indonesia (MUI) dalam rangka secara terus-menerus melakukan penelitian dan selanjutnya memberikan label halal terhadap pelbagai jenis makanan, kosmetik dan daging olahan yang beredar di masyarakat dalam pelbagai kemasan secara kontinu terus dilaksanakan dalam upaya memberikan kepastian status makanan yang akan dikonsumsi dan produk kosmetik yang akan dipakai.

Pangan halal merupakan pangan yang memenuhi syariat agama Islam baik dari segi bahan baku, bahan tambahan yang digunakan maupun cara produksinya sehingga pangan tersebut dapat dikonsumsi oleh orang Islam tanpa berdosa. ${ }^{6}$ Oleh karenanya pada bahan pangan yang dikonsumsi tidak boleh ada kontaminasi dengan bahan yang meragukan sedikit pun, apalagi dengan yang haram sehingga menyebabkan produk pangan menjadi syubhat atau diragukan kehalalannya.

Produk halal adalah produk yang memenuhi syarat kehalalan sesuai dengan syariat Islam, yaitu: (1) Tidak mengandung babi dan bahan yang berasal dari babi. (2) Tidak mengandung bahan-bahan yang diharamkan seperti bahan-bahan yang berasal dari organ manusia, darah, kotoran dan lain-lain. (3) Semua bahan yang berasal dari hewan halal yang disembelih menurut tata cara syariat Islam. (4) Semua tempat penyimpanan, penjualan, pengolahan, tempat pengelolaan dan transportasinya tidak boleh digunakan untuk babi. Jika pernah digunakan untuk babi atau barang yang tidak halal lainnya maka terlebih dahulu harus dibersihkan dengan tata cara yang diatur menurut syariat Islam.(5) Semua makanan dan minuman yang tidak mengandung khamar. $^{7}$

Ada dua urgensi sertifikasi halal, yaitu: (1) Pada aspek

${ }^{4}$ Departemen Agama Republik Indonesia, Panduan Sertifikasi Halal, h. 3.

5 "Apa Itu Makanan Halal...??, dalam www.zona-sosial.blogspot. com, diunduh tanggal 17 Maret 2013.

${ }^{6}$ Moh. Anas Muchtar, "Pentingnya Sertifikasi Halal Melalui LPPOM dan MUI", dalam www.madinatualim.com, diunduh pada tanggal 17 Maret 2013.

${ }^{7}$ Departemen Agama, Panduan Sertifikasi Halal, h. 2. 
moral sebagai bentuk pertanggungjawaban produsen kepada konsumen. (2) Pada aspek bisnis sebagai sarana pemasaran, meningkatnya kepercayaan dan kepuasan konsumen. ${ }^{8}$

UU No. 18 Tahun 2009 tentang Peternakan dan Kesehatan Hewan juga mengatur tentang kehalalan dalam Pasal 58 yang menyebutkan bahwa Pemerintah dan Pemerintah Daerah sesuai kewenangannya melaksanakan pengawasan, pemeriksaan, pengujian, standarisasi, sertifikasi dan registrasi dalam rangka menjamin produk hewan yang aman, sehat, utuh dan halal. Kemudian dikenal ada Sistem Jaminan Halal (SJH) yaitu sebuah sistem yang mengelaborasi, menghubungkan, mengakomodasi dan mengintegrasikan konsep-konsep syariat Islam khususnya terkait dengan halal dan haram, etika usaha dan manajemen keseluruhan, prosedur dan mekanisme perencanaan serta implementasi dan evaluasinya pada suatu rangkaian produksi atau olahan bahan yang akan dikonsumsi umat Islam. ${ }^{?}$

Prinsip sistem jaminan halal pada dasarnya mengacu pada konsep Total Quality Manajement (TQM) yaitu sistem manajemen kualitas terpadu yang menekankan pengendalian kualitas pada setiap lini. Sistem jaminan halal harus dipadukan dalam keseluruhan manajemen yang berpijak pada empat konsep dasar, yaitu komitmen yang kuat untuk memenuhi permintaan dan persyaratan konsumen, meningkatkan mutu produksi dengan harga yang terjangkau, produksi bebas dari kerja ulang serta bebas dari penolakan dan penyidikan. ${ }^{10}$

Oleh karena itu maka penting untuk memberikan label halal pada setiap kemasan makanan yang akan diproduksi agar kaum Muslim merasa aman mengkonsumsinya dan terbebas dari dosa. Pemberian label halal pada pangan yang dikemas bertujuan agar masyarakat memperoleh informasi yang benar dan jelas atas setiap produk pangan, baik menyangkut asal, keamanan, mutu, kandungan gizi maupun keterangan lain yang diperlukan.

Khusus pencantuman label halal ditujukan untuk melindungi masyarakat yang beragama Islam agar terhindar dari produk makanan yang tidak halal. Dengan adanya labelisasi halal dapat dijadikan sebagai tanda yang memudahkan konsumen untuk memilih produk-produk pangan yang akan dikonsumsinya

8 "Apa itu Makanan Halal...??", dalam www.zona-sosial.blogspot. com, diunduh pada tanggal 17 Maret 2013.

9 "Pentingnya Sertifikasi Halal untuk Produk Makanan Indonesia (Halal Sertification Acquire For Indonesian Food)", dalam www. duniailmupeternakan.blogspot.com, diunduh tanggal 14 Maret 2013.

10 "Apa itu Makanan Halal...??", dalam www.zona-sosial.blogspot. com, diunduh pada tanggal 17 Maret 2013. sesuai dengan keyakinan agama Islam yang dianutnya. ${ }^{11}$

Untuk mencapai hal tersebut perlu menekankan pada tiga aspek yaitu zero limit, zero defect dan zero risk. Dengan penekanan pada 3 zero tersebut tidak boleh ada sedikit pun unsur haram, tidak boleh ada proses yang menimbulkan ketidakhalalan produk dan tidak menimbulkan risiko dengan penerapannya. Oleh karena itu perlu ada komitmen dari seluruh bagian operasional manajemen, mulai dari pengadaan bahan baku sampai distribusi pemasaran. ${ }^{12}$

Sistem jaminan halal dalam penerapannya harus diuraikan secara tertulis dalam bentuk manual halal yang meliputi lima aspek, yaitu: (1) Pernyataan kebijakan perusahaan tentang halal (halal policy), (2) Panduan halal (halal guidelines), (3) Sistem organisasi halal, (4) Uraian titik kendali kritis keharaman produk, dan (5)Sistem audit halal internal. ${ }^{13}$

Manual halal harus dibuat secara terperinci disesuaikan dengan kondisi masing-masing perusahaan agar dapat dilaksanakan dengan baik. Manual halal merupakan sistem yang mengikat seluruh elemen perusahaan. Dengan demikian harus disosialisasikan kepada seluruh karyawan di lingkungan perusahaan. Secara teknis, manual halal harus dijabarkan dalam bentuk prosedur pelaksanaan baku (Standard Operating Prosedure/SOP) untuk tiap bidang yang terlibat dalam produksi halal.

\section{Etika Bisnis dalam Islam}

Etika berasal dari bahasa bahasa Yunani (Greek) yaitu ethos dalam bentuk jamaknya ( $t a$ etha) yang berarti "adat istiadat" atau "kebiasaan". ${ }^{14}$ Etika adalah a code or self of principle which people live (kaidah atau seperangkat prinsip yang mengatur hidup manusia). ${ }^{15}$ Ini berarti secara etimologi, etika identik dengan moral karena telah umum diketahui bahwa istilah moral berasal dari kata mos (dalam bentuk tunggal) dan mores (dalam bentuk jamak) dalam bahasa Latin yang artinya kebiasaan atau cara hidup. ${ }^{16}$

Moral berasal dari bahasa Inggris yaitu moral, bahasa

11 "Apa itu Makanan Halal...??”, dalam www.zona-sosial.blogspot. com, diunduh pada tanggal 17 Maret 2013.

12 "Apa itu Makanan Halal...??”, dalam www.zona-sosial.blogspot. com, diunduh pada tanggal 17 Maret 2013.

13 "Apa itu Makanan Halal...??”, dalam www.zona-sosial.blogspot. com, diunduh pada tanggal 17 Maret 2013.

14 A. Sony Keraf, Etika Bisnis Tuntutan dan Relevansinya, (Yogyakarta: Kanisius, 2005), Cet.VIII, h. 14.

15 Mohamad Hidayat, An Intoduction The Sharia Economic Pengantar Ekonomi Syariah, (Jakarta: Zikrul Hakim, 2010), h. 48.

${ }^{16}$ Sondang P. Siagiaan, Etika Bisnis, (Jakarta: Pustaka Binaman Pressindo, 1996), h. 2. 
Latin mores dan bahasa Belanda moural yang bermakna budi pekerti, kesusilaan dan adat kebiasaan. Secara terminologi, etika adalah ilmu pengetahuan tentang moral (kesusilaan). Setiap orang memiliki moralitasnya masing-masing namun tidak semua orang perlu melakukan pemikiran secara kritis terhadap moralitas yang menjadi kegiatan etika. ${ }^{17}$ Etika ialah teori tentang perilaku perbuatan manusia dipandang dari nilai baik dan buruk sejauh yang dapat ditentukan oleh akal. ${ }^{18}$

Secara filosofis esensi makna dari dua istilah (moral dan etika) itu dapat dibedakan. Menurut Frans Magnis Suseno yang dimaksud dengan moral adalah ajaranajaran, wejangan-wejangan, patokan-patokan, lisan atau tertulis tentang bagaimana manusia harus hidup dan bertindak agar ia menjadi manusia yang baik. Etika adalah filsafat atau pemikiran kritis dan mendasar tentang ajaran-ajaran dan pandangan moral. ${ }^{19}$ Dengan demikian etika adalah ilmu pengetahuan tentang moral (kesusilaan).

Dalam Islam istilah moral identik dengan akhlâq. Kata akhlâq merupakan bentuk jama' dari kata khalq yang bermakna budi pekerti, menghargai, tingkah laku dan tabiat. ${ }^{20}$ Akhlak berarti character, disposition dan moral constitution. ${ }^{21}$ Secara linguistik perkataan akblâq ialah bentuk jamak dari khuluq yang berarti budi pekerti, perangai, tingkah laku atau tabiat. ${ }^{22}$

Walaupun dikenal dengan banyak istilah yang dipakai, namun baik akhlak, moral, etika, tata krama, sopan santun, susila, budi pekerti, tingkah laku, perangai maupun tabiat, semuanya mempunyai makna yang identik dan hanya dipisahkan oleh sumber, standar dan asal-muasal terminologi tersebut.

Etika lebih bersifat teori dan moral bersifat praktik. Etika membicarakan bagaimana seharusnya sedangkan moral bagaimana adanya. Etika menyelidiki, memikirkan dan mempertimbangkan tentang yang baik dan buruk, moral menyatakan ukuran yang baik tentang tindakan manusia dalam kesatuan sosial tertentu. Etika memandang laku-perbuatan manusia secara universal,

\footnotetext{
${ }^{17}$ Suparman Usman, Hukum Islam Asas-Asas dan Pengantar Studi Hukum Islam dalam Tata Hukum Indonesia, (Jakarta: Gaya Media Pratama, 2001), h. 78.

${ }_{18}$ Sidi Gazalba, Sistematika Filsafat, Buku Keempat Pengantar kepada Teori Nilai, (Jakarta: Bulan Bintang, 2002), h. 50.

${ }^{19}$ Frans Magnis Suseno, Etika Dasar: Masalah Pokok Filsafat Moral, (Yogyakarta: Kanisius, 1991), Cet. III, h. 14.

${ }^{20}$ Louis Ma’lûf, Lisân al-Arab, (Bayrût: al-Maktabah al-Kulliyah, t.th.), h. 194.

${ }^{21}$ Muhaimin, et.al., Kawasan dan Wawasan Studi Islam, (Jakarta: Prenada Media, 2005), h. 262.

${ }^{22}$ A. Mustofa, Akblak Tasawuf, (Bandung: Pustaka Setia. 1997) h. 11. Lihat juga Ismail Thaib, Risalah Akhlaq, (Yogyakarta:CV.Bina Usaha.1984), h. 1.
}

moral secara temporal. Moral menyatakan ukuran, etika menjelaskan ukuran itu. Moral sesungguhnya dibentuk oleh etika. Ia merupakan muara atau buah dari etika. ${ }^{23}$

Ekonomi menurut pandangan Islam bukanlah semata sebuah tujuan tetapi merupakan kebutuhan dan sarana yang lazim bagi manusia agar bisa bertahan hidup dan bekerja untuk mencapai tujuannya yang tinggi. Ekonomi merupakan sarana penunjang bagi manusia dan menjadi pelayan akidah Islam serta risalahnya. ${ }^{24}$

Sistem bisnis ekonomi dalam pandangan Islam memiliki pengawasan internal atau hati nurani yang ditumbuhkan oleh iman di dalam hati seorang Muslim dan menjadikan pengawas bagi dirinya. Ekonomi Islam bertujuan untuk memungkinkan manusia memenuhi kebutuhan hidupnya yang disyariatkan oleh Allah swt. Manusia perlu hidup dengan pola kehidupan yang rabbanî sekaligus manusiawi sehingga ia mampu melaksanakan kewajibannya kepada Tuhan, diri dan keluarganya serta sesama manusia. ${ }^{25}$

Secara umum pedoman tentang masalah bisnis dalam Islam yaitu tidak membolehkan umatnya untuk bekerja mencari uang sesuka hatinya dan dengan jalan apapun seperti penipuan, curang, sumpah palsu dan perbuatan batil lainnya. ${ }^{26}$ Implementasi nilai-nilai moralitas tersebut dalam bisnis merupakan tanggung jawab bagi setiap pelaku bisnis. Bagi seorang Muslim nilai-nilai ini merupakan refleksi dari keimanannya kepada Allah.

Husayn Syahathah dan Shiddîq Muhammad alAmîn al-Dhâhir menjelaskan alasan etika dalam berbisnis sangat diperlukan yaitu: (1) Terjadinya kerusakan moral yang semakin meluas pada perusahaan akhir-akhir ini. (2) Studi lapangan menunjukkan bahwa kuatnya pemberdayaan etika yang unggul dapat membawa nama baik perusahaan. ${ }^{27}$ Pada dasarnya etika berpengaruh terhadap pelaku bisnis terutama dalam hal kepribadian, tindakan dan perilaku. ${ }^{28}$

\footnotetext{
${ }^{23}$ Sidi Gazalba, Sistematika Filsafat, h. 52.

${ }^{24}$ Veithzal Rivai dan Andi Buchari, Islamic Economics Ekonomi Syariah Bukan OPSI, Tetapi SOLUSI!, (Jakarta: Bumi Aksara, 2009),

${ }^{25}$ Veithzal Rivai dan Andi Buchari, Islamic Economics Ekonomi, h.

${ }^{26}$ Akhmad Mujahidin. "Etika Bisnis Dalam Islam (Analisis Terhadap Aspek Moralitas Pelaku Bisnis)", dalam Majalah Hukum Islam, Vol. IV, No. 2 Desember 2005, h. 117.

${ }^{27}$ Mohamad Hidayat, An Introduction to The Sharia Economic; Pe gantar Ekonomi Syraiah, (Jakarta: Zikrul Hakim, 2010), h. 49.

${ }^{28}$ Husayn Syahathah, Shiddîq Muhammad al-Amîn al-Dhâhir, Transaksi dan Etika Bisnis Islam, Terjemahan dari Business Ethics in Islam \& al-Gharar fî al-'Uqûd wa Atsâruha fî al-Thathbîq al-Mu'ashirah, penterjemah Saptomo Budi Satryo dan Fauziah, (Jakarta: Visi Insani Publishing, 2005) h. 51.
} h. 91. 93. 
Aturan main bisnis Islam menjelaskan pelbagai etika yang harus dilakukan oleh para pebisnis Muslim dalam melaksanakan aktivitas bisnisnya. Diharapkan dengan menggunakan dan mematuhi etika bisnis Islam tersebut usaha perdagangan seorang Muslim akan maju dan berkembang pesat lantaran selalu mendapat berkah Allah swt di dunia dan akhirat.

Bisnis dalam Islam diartikan sebagai serangkaian aktivitas bisnis dalam pelbagai bentuknya (yang tidak dibatasi) namun dibatasi dalam cara perolehan dan pendayagunaan hartanya (ada aturan halal dan haram). Artinya pelaksanaan bisnis harus tetap berpegang pada ketentuan syariat (aturan-aturan dalam Alquran dan Hadis). Dengan kata lain, syariat merupakan nilai utama yang menjadi payung strategis maupun taktis bagi pelaku kegiatan ekonomi bisnis. ${ }^{29}$

Adapun etika perdagangan dalam Islam antara lain: pertama, shidiq (jujur). Seorang pedagang wajib berlaku jujur dalam melakukan usaha jual-beli. Jujur dalam arti luas adalah tidak berbohong, tidak menipu, tidak mengada-ada fakta, tidak berkhianat serta tidak pernah ingkar janji dan lain sebagainya. ${ }^{30}$ Pelbagai tindakan tidak jujur, selain merupakan perbuatan yang jelas-jelas berdosa, jika biasa dilakukan dalam berbisnis juga akan mewarnai dan berpengaruh negatif pada kehidupan pribadi dan keluarga itu sendiri.

Kedua, amanah (tanggung jawab). Amanah ini ditampilkan dalam keterbukaan, kejujuran, pelayanan yang optimal dan ihsan (kebajikan) dalam segala hal. ${ }^{31}$ Maknanya adalah bahwa setiap pedagang harus bertanggung jawab atas usaha serta pekerjaan sebagai pedagang. Tanggung jawab dalam hal ini artinya mau dan mampu menjaga amanah (kepercayaan) masyarakat yang memang secara otomatis terbeban di pundaknya. Tanggung jawab pedagang di sini misalnya menyediakan barang atau jasa kebutuhan masyarakat dengan harga yang wajar, jumlah yang cukup serta kegunaan dan manfaat yang memadai. ${ }^{32}$ Oleh sebab itu para pedagang dilarang keras untuk melakukan penimbunan barang dagangannya.

Ketiga, tidak menipu. Pasar merupakan tempat orang bertemu dengan beragam latar belakang yang berbeda dan tentunya sangat potensial untuk terjadinya

${ }^{29}$ Veithzal Rivai, Amiur Nuruddin, Faisar Ananda Arfa, Islamic Business And Economics Ethics Mengacu pada Al-Qur'an dan Mengikuti Jejak Rasulullah Saw dalam Bisnis, Keuangan dan Ekonomi, (Jakarta: PT Bumi Aksara, 2012), h. 13.

${ }^{30}$ Suryadhie, "Etika Perdagangan Islam", dalam www.suryadhie/ wordpress.com, diunduh tanggal 13 Maret 2012.

${ }^{31}$ Veithzal Rivai dan Andi Buchari, Islamic Economics Ekonomi, h. 236.

${ }^{32}$ Suryadhie, "Etika Perdagangan Islam", h. 6. pelbagai macam tindak kejahatan dalam transaksi perdagangan. Pasar juga disinyalir di dalamnya penuh dengan penipuan, sumpah palsu, janji palsu, keserakahan, perselisihan dan keburukan tingkah laku pola manusia lainnya. ${ }^{33}$

Keempat, menepati janji. Seorang yang berprofesi sebagai pedagang dituntut untuk selalu menepati janjinya, baik kepada pembeli maupun diantara sesama pedagang, terlebih lagi janji kepada Allah Swt. Janji yang harus ditepati oleh para pedagang kepada pembeli misalnya tepat waktu pengiriman, menyerahkan barang yang kualitas, kuantitas, warna, ukuran atau spesifikasinya sesuai dengan perjanjian semula, memberi pelayanan purna jual, garansi dan lain-lain. Sementara janji yang harus ditepati kepada sesama pedagang misalnya pembayaran dengan jumlah dan waktu yang tepat.

Kelima, murah hati. Murah hati di sini dalam konteks ramah tamah, sopan santun, murah senyum dan suka mengalah namun tetap penuh tanggung jawab. Ada Hadis Rasulullah Saw. yang memerintahkan kepada para pedagang untuk bermurah hati dalam melaksanakan jual beli. ${ }^{34}$

Keenam, tidak melupakan akhirat. Jual beli atau perdagangan merupakan aktivitas duniawi sedangkan melaksanakan kewajiban syariat Islam adalah aktivitas ruhani yang menuju akhirat. Keuntungan akhirat pasti lebih utama dibanding keuntungan dunia. Maka para pedagang Muslim tidak boleh terlalu banyak menyibukkan dirinya semata-mata untuk mencari keuntungan materi dengan meninggalkan keuntungan akhirat. Maka jika waktu shalat telah tiba mereka wajib melaksanakannya sebelum habis waktunya.

Ketujuh, kesadaran tentang signifikansi sosial kegiatan bisnis. Pelaku bisnis menurut Islam tidak hanya sekedar mengejar keuntungan sebanyak-banyaknya (profit oriented) seperti doktrin ekonomi kapitalis tetapi juga berorientasi kepada sifat ta'âwun (tolongmenolong) sebagai implikasi sosial kegiatan bisnis. Intinya adalah bahwa berbisnis bukan mencari untung material semata tetapi didasari kesadaran memberi kemudahan bagi orang lain dengan menjual barang.

Kedelapan, tidak boleh monopoli. Salah satu perangai buruk sistem ekonomi kapitalis adalah melegitimasi monopoli dan oligopoli. Misalnya adalah eksploitasi individu tertentu atas hak milik sosial seperti air, udara, tanah dan kandungan isinya. Individu tersebut mengeruk keuntungan secara pribadi tanpa memberi

\footnotetext{
${ }^{33}$ Suryadhie, "Etika Perdagangan Islam", h. 7.

${ }^{34}$ Suryadhie, "Etika Perdagangan Islam”, h. 10.
} 
kesempatan kepada orang lain.

Kesembilan, tidak boleh melakukan bisnis dalam kondisi mudarat yang dapat merugikan dan merusak kehidupan individu dan sosial, misalnya tidak boleh menjual barang halal seperti anggur kepada produsen minuman keras. Oleh karena itu, semua bentuk bisnis yang dapat memberikan kemudaratan atau merusak esensi hubungan sosial antara manusia dengan manusia lainnya dilarang dengan tegas

Kesepuluh, komoditi bisnis yang dijual adalah barang yang suci dan halal, bukan barang yang haram. Oleh karena itu tidak boleh menjual anjing, babi, minuman keras, obat-obat terlarang dan lain-lain.

Kesebelas, bisnis yang dilakukan harus bersih dari unsur maysir (judi), gharar (penipuan) dan riba. Walaupun para ulama berbeda dalam mendefinisikan riba namun ada satu garis lurus yang mensinonimkan hubungan antara definisi satu dengan yang lain yaitu bahwa riba merupakan pengambilan tambahan dalam transaksi jual beli atau utang-piutang secara batil atau bertentangan dengan prinsip muamalat Islam. ${ }^{35}$ Prinsip utama dari riba adalah penambahan, yaitu penambahan atas harta pokok tanpa adanya transaksi bisnis yang riil.

\section{Sertifikasi dan Labelisasi Halal sebagai Wujud Perlindungan Konsumen Muslim}

Aktivitas bisnis merupakan bagian integral dari wacana ekonomi. Sistem ekonomi Islam berangkat dari kesadaran tentang etika, sedangkan sistem ekonomi lain seperti kapitalisme dan sosialisme cenderung mengabaikan etika sehingga aspek nilai tidak begitu tampak dalam bangunan kedua sistem ekonomi tersebut. Keringnya kedua sistem tersebut dari wacana moralitas karena keduanya memang tidak berangkat dari etika tetapi dari kepentingan (interest). ${ }^{36}$ Islam memiliki prinsip-prinsip tersendiri dalam kegiatan ekonomi yang bersumber dari Alquran dan Hadis. Prinsip-prinsip tersebut bersifat abadi, seperti prinsip tauhid, adil, maslahat, kebebasan disertai tanggung jawab, persaudaraan dan sebagainya. ${ }^{37}$

Adanya regulasi tentang sertifikasi halal sebuah produk baik makanan, obat-obatan maupun kosmetik merupakan bagian dari perlindungan terhadap konsumen khususnya yang beragama Islam. Islam sendiri

\footnotetext{
${ }^{35}$ Azhari Akmal Tarigan, "Riba Dalam Al-Quran", dalam Harian Waspada, edisi Jumat, 2 Januari 2004.

36 Veithzal Rivai, Amiur Nuruddin,Faisar Ananda Arfa, Islamic Business And Economics, h. 36.

${ }^{37}$ Veithzal Rivai, Amiur Nuruddin,Faisar Ananda Arfa, Islamic Business And Economics, h. 49.
}

dalam ajarannya diperintahkan untuk mengkonsumsi produk yang halal. Dari segi makanan dan barang, orang-orang Islam diperintahkan supaya memakan dan menggunakan bahan-bahan yang baik, suci dan bersih. Hal itu termaktub dalam Alquran:

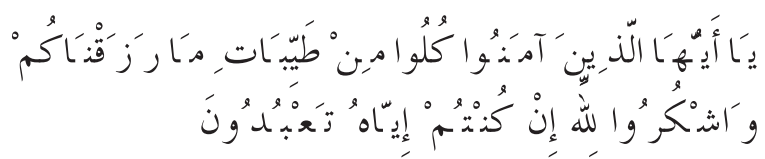

Wahai orang-orang yang beriman, makanlah dari bendabenda yang baik (yang halal) yang telah Kami berikan kepada kamu dan bersyukurlah kepada Allah jika betul kamu hanya beribadat kepada-Nya. (Q.s. Al-Baqarah [2]: 172)

Kebersihan, kesucian dan baik atau buruk sesuatu makanan dan barang yang digunakan oleh orangorang Islam senantiasa terkait dengan hukum halal dan haram $^{38}$. Oleh karena itu umat Islan perlu mengetahui informasi yang jelas tentang halal dan haram dalam aspek makanan, minuman, obat, kosmetika dan pelbagai jenis barang lainnya yang sering dikonsumsi oleh umat Islam.

Penentuan status halal haramnya sebuah produk baik makanan, obat-obatan atau kosmetik bukanlah perkara mudah. Pada satu sisi para ulama mungkin belum seluruhnya menyadari betapa banyaknya produk pangan, obat dan kosmetik saat ini. Asal usul bahan bisa melalui jalur yang berliku, bahkan dalam beberapa kasus sulit untuk ditentukan asal bahannya. Dalam sisi lain, pemahaman para ilmuwan terhadap syariat Islam, ushul fikih dan metodologi penentuan halal haramnya suatu bahan pangan relatif minim. Dengan demikian, seharusnya para ulama mencoba memahami betapa kompleksnya produk pangan, obat dan kosmetik. Sedangkan ilmuwan Muslim seharusnya menggali kembali pengetahuan syariatnya untuk membantu ulama memahami kompleksitas masalah yang ada. ${ }^{39}$

Sebagai negara dengan penduduk Muslim terbesar di dunia, sudah selaiknya Indonesia menjadi pilot project untuk menerapkan regulasi produk pangan, kosmetika dan obat-obatan dengan sertifikasi dan label halal. Senada dengan itu pula Majelis Ulama Indonesia (MUI) berharap ada kewajiban dari pengusaha untuk mensertifikatkan produk halal tersebut. ${ }^{40}$

${ }^{38}$ Departemen Agama RI, Bunga Rampai Jaminan Produk Halal di Negara Anggota MABIMAS, (Jakarta: Bagian Proyek Sarana dan Prasarana Produk Halal Direktorat Jenderal Bimbingan Masyarakat Islam dan Penyelenggaraan Ibadah Haji Departemen Agama R.I., 2003), h. 21.

39 Apriyantono, "Penentuan Kehalalan Produk Pangan Hasil Bioteknologi: Suatu Tantangan”, dalam www.indohalal.com., diunduh tanggal 11 Februari 2009.

40 "Perlu Aturan yang Wajibkan Pengusaha Cantumkan Label Halal", dalam www.jurnal-ekonomi.org, diunduh tanggal 11 Februari 2009. 
Menurut Ibrahim Hosen, produk-produk olahan baik makanan, minuman, obat-obatan maupun kosmetika dikategorikan ke dalam kelompok mutasyâbihât (syubhat). Apalagi jika produk tersebut berasal dari negeri yang penduduknya mayoritas non Muslim sekalipun bahan bakunya berupa barang suci dan halal. ${ }^{41}$

Perlindungan atas konsumen merupakan hal yang sangat penting dalam hukum Islam. Islam melihat sebuah perlindungan konsumen bukan sebagai hubungan keperdataan semata melainkan menyangkut kepentingan publik secara luas bahkan menyangkut hubungan antara manusia dengan Allah Swt. Dalam konsep hukum Islam perlindungan atas tubuh terkait dengan hubungan vertikal (manusia dengan Allah Swt) dan horizontal (sesama manusia). Dalam Islam, melindungi manusia dan juga masyarakat sudah merupakan kewajiban sebuah negara sehingga melindungi konsumen atas barang-barang yang sesuai dengan kaidah Islam harus diperhatikan secara fokus dan serius.

Telaah terhadap perlindungan konsumen Muslim atas produk barang dan jasa menjadi sangat penting setidaknya disebabkan oleh beberapa hal, antara lain: Pertama, bahwa konsumen Indonesia mayoritas merupakan konsumen beragama Islam yang sudah selaiknya mendapatkan perlindungan atas segala jenis produk barang dan jasa yang sesuai dengan kaidah-kaidah hukum Islam. Berdasarkan hal tersebut maka masyarakat Islam (konsumen Muslim) harus mendapatkan perlindungan atas kualitas mutu barang dan jasa serta tingkat kehalalan suatu barang dan jasa yang ditawarkan oleh pelaku usaha.

Kedua, bahwa Pemerintah Indonesia sudah melakukan upaya aktif untuk melindungi konsumenkonsumen yang mayoritas beragama Islam. Perlindungan konsumen merupakan hak warga negara yang pada sisi lain merupakan kewajiban negara untuk melindungi warga negaranya khususnya atas produk yang halal dan baik. $^{42}$

Menurut UU No. 8 Tahun 1999 tentang Perlindungan Konsumen pada Pasal 4 (a) disebutkan bahwa hak konsumen adalah hak atas kenyamanan, keamanan dan keselamatan dalam mengkonsumsi barang dan/atau jasa. Pasal ini menunjukkan bahwa setiap konsumen, termasuk konsumen Muslim yang

\footnotetext{
${ }^{41}$ Mara Gandhi Prataman Tanjung, Penerapan Etika Bisnis Islam sebagai Perlindungan Konsumen pada Penjualan Makanan Berlabel Halal, Skripsi, (Medan: Fakultas Hukum Universitas Muhammadiyah Sumatera Utara, 2009), h. 37.

${ }^{42}$ Fokky, "Perlindungan Konsumen Pangan dalam Perspektif I lam”, dalamwww.uai.ac.id., diunduh tanggal 10 Maret 2009.
}

merupakan mayoritas konsumen di Indonesia, berhak untuk mendapatkan barang yang nyaman untuk dikonsumsi. Salah satu pengertian nyaman bagi konsumen Muslim adalah bahwa barang tersebut tidak bertentangan dengan kaidah agamanya yang dalam terminologi lain adalah halal.

Dalam pasal yang sama poin (c) disebutkan bahwa konsumen juga berhak atas informasi yang benar, jelas dan jujur mengenai kondisi dan jaminan barang dan/atau jasa. Hal ini memberikan pengertian bahwa keterangan halal yang diberikan oleh perusahaan haruslah benar atau telah teruji terlebih dahulu. Dengan demikian perusahaan tidak dapat mengklaim secara langsung bahwa produknya halal sebelum melalui pengujian kehalalan yang telah ditentukan. ${ }^{43}$

Aspek keamanan dan ketenangan batin itulah yang diinginkan oleh setiap Muslim ketika menggunakan sebuah produk makanan, obat-obatan dan kosmetik. Oleh karena itu konsumen perlu mendapatkan sebuah kepastian hukum bahwa produk yang digunakan tidak mengandung sesuatu yang tidak halal dan juga diproduksi secara halal.

Adanya sertifikasi serta labelisasi halal bukan saja bertujuan memberi ketentraman batin pada umat Islam tetapi juga ketenangan berproduksi bagi produsen. Untuk menghadapi globalisasi ekonomi yang semakin nyata maka sertifikasi dan labelisasi halal semakin diperlukan untuk melindungi konsumen Muslim.

Kewajiban produsen untuk melakukan sertifikasi halal telah ada berdasarkan UU No.7 Tahun 1996 tentang Pangan dan UU No. 8 Tahun 1999 tentang Perlindungan Konsumen. Walaupun demikian, masih banyak produsen makanan atau barang yang belum mengajukan dan memiliki sertifikasi halal.

Pada dasarnya sertifikasi halal tidak cuma menguntungkan konsumen tetapi juga produsen. Dengan produk halal maka kepercayaan dan loyalitas konsumen akan meningkat. Selain itu, jika produk itu halal maka pasarnya bisa menjangkau semua kalangan, baik Muslim maupun non Muslim. ${ }^{44}$

Penentuan kehalalan suatu produk ditetapkan dalam rapat Komisi Fatwa MUI yang didasarkan pada hasil laporan auditing dari LPPOM-MUI. Sebuah produk yang telah dinyatakan halal akan mendapatkan sertifikasi halal dari MUI. Sertifikat halal berlaku selama dua tahun dan setelah masa itu produk harus diperiksa

\footnotetext{
${ }^{43}$ Lukmanul Hakim, Labelisasi Halal sebagai Wujud Perlindungan Konsumen, Makalah, (Jakarta: Lembaga Pengkajian Pangan, Obatobatan dan Kosmetika Majelis Ulama Indonesia,2004), h. 4.

${ }_{44}$ Hasan, "Label Halal", dalam www.hasan.sayanginanda.com, diunduh tanggal 11 Februari 2009.
} 
ulang untuk mendapatkan sertifikat halal untuk 2 tahun berikutnya. Lembaga yang berwenang memberikan izin pencantuman label halal pada kemasan obat/makanan adalah BPOM. Izin pencantuman label halal diberikan setelah suatu produk dinyatakan halal (telah memiliki sertifikat halal).

Adapun beberapa manfaat label halal bagi produsen antara lain: (1) Memilki USP (Unic Selling Point). (2) Meningkatkan kepercayaan konsumen atas produk yang dikeluarkannya. (3) Kesempatan untuk meraih pasar pangan halal global yang diperkirakan sebanyak 1,4 milyar Muslim dan jutaan non Muslim lainnya. (4) Sertifikasi halal adalah jaminan yang dapat dipercaya untuk mendukung klaim pangan halal. (5) $100 \%$ keuntungan dari market share yang lebih besar tanpa kerugian dari pasar/klien non Muslim. (6) Meningkatkan marketability produk di pasar/negara Muslim. (7) Investasi berbiaya murah dibandingkan dengan pertumbuhan revenue yang dapat dicapai. (8) Peningkatan citra produk. ${ }^{45}$

Sebagai bentuk tanggung jawab terhadap hal tersebut maka LPPOM-MUI selaku lembaga pemberi sertifikat halal di Indonesia menganut dan menerapkan prinsip zero tolerance atau halal harus $100 \%$. Jika tidak memenuhi prinsip tersebut maka berarti tidak halal dan wajib dihindari. ${ }^{46}$

Halal dan baik merupakan dua unsur yang tidak dapat dipisahkan dalam pangan yang dikonsumsi. Halal merupakan pemenuhan dari segi syariat dan "baik" dari segi mutu, kesehatan, gizi dan organoleptik. Untuk menyediakan makanan yang baik, pelbagai sistem dan peraturan telah distandarkan dan diimplementasikan.

Mengkonsumsi pangan haram akan memberikan banyak dampak yang tidak baik bukan hanya menimbulkan penyakit secara fisik melainkan juga penyakit secara mental/spritual. Konsumsi pangan tidak halal merupakan dosa pertama yang dilakukan oleh nenek moyang manusia (Nabi Adam As.) yang menyebabkannya dikeluarkan dari surga. Selain itu konsumsi pangan tidak halal mengakibatkan doa tidak diterima, ibadah ditolak oleh Allah Swt dan susah taat serta senang maksiat. ${ }^{47}$

Prinsip etika dalam produksi yang wajib dilaksanakan oleh setiap Muslim baik individu maupun komunitas

45 “Apa itu Makanan Halal...??”, dalam www.zona-sosial.blogspot. com, diunduh pada tanggal 17 Maret 2013.

${ }^{46}$ Moh.Anas Muchtar, "Pentingnya Sertifikasi Halal Melalui L POM dan MUI", dalam www.madinatualim.com, diunduh pada tanggal 17 Maret 2013.

47 Moh.Anas Muchtar, "Pentingnya Sertifikasi Halal Melalui LPPOM dan MUI", dalam www.madinatualim.com, diunduh pada tanggal 17 Maret 2013 adalah berpegang pada semua yang dihalalkan oleh Allah dan tidak melewati batas. Pada dasarnya produsen pada tatanan ekonomi konvensional tidak mengenal istilah halal dan haram, tetapi yang ada adalah untung dan rugi. Prioritas bagi para pengusaha liberalis adalah memenuhi keinginan pribadi dengan mengumpulkan laba, harta dan uang. Produsen yang dilahirkan dalam pola pikir liberalis itu tidak mementingkan apakah yang diproduksinya itu bermanfaat atau berbahaya, baik atau buruk dan etis atau tidak etis.

Islam melalui syariatnya tidak membenarkan membuat segala komoditi yang hanya digunakan untuk hal yang diharamkan atau sebagian besar barang itu digunakan untuk berbuat dosa, walaupun sebagian kecil komoditi tersebut dapat digunakan untuk halhal yang diperbolehkan. Sebab sebagian kecil dan hal yang jarang ini tidak bisa dijadikan pijakan bagi suatu hukum. $^{48}$

Islam dalam doktrin bisnisnya menerapkan asas keseimbangan antara seluruh kepentingan, baik untuk produsen maupun konsumen. Islam menerapkan sistem ekonominya dengan mempergunakan moral dan hukum bersama untuk menegakkan bangunan suatu sistem yang praktis. Berkenaan dengan prioritas, Islam mengetengahkan konsep keseimbangan antara kepentingan individu (khusus) dan kepentingan negara (umum) yang bersumber pada Alquran dan Sunah. ${ }^{4}{ }^{9}$

Oleh karena itu, dalam konteks Indonesia, gerakan bisnis berbasis syariat telah berkembang dengan sangat cepat. Bisnis Islami merupakan serangkaian aktivitas bisnis dalam pelbagai bentuknya yang tidak dibatasi jumlah (kuantitas) kepemilikan hartanya (barang/ jasa) termasuk profitnya namun dibatasi dalam cara perolehan dan pendayagunaan hartanya (ada aturan halal dan haram). ${ }^{50}$

Pada tataran praktik di Indonesia usaha untuk memberikan proteksi terhadap hak-hak konsumen Muslim dinyatakan melalui Surat Keputusan (SK) Menteri Agama Nomor 518 tanggal 30 November 2011 tentang Tata Cara Pemeriksaan dan Penetapan Pangan Halal. Tampaknya Pemerintah berusaha kembali menerapkan labelisasi halal pada produk makanan dan minuman.

Keputusan tersebut disusul dengan SK Menteri Agama Nomor 519 Tahun 2001 yang menunjuk

\footnotetext{
${ }^{48}$ YusufQaradhawi, Norma dan Etika Ekonomi Islam, (Jakarta:Gema Insani Press, 1997), h. 127.

${ }^{49}$ Nejatullah Siddiqi, Kemitraan Usaha dan Bagi Hasil dalam Hukum Islam, (Jakarta: Dana Bakti Prima Yasa, 1996), h. 19.

${ }^{50}$ M.Ismail Yusanto dan M.Karebet Widjajakusuma, Menggagas Bisnis Islami, (Jakarta: Gema Insani Press, 2002), h. 18.
} 
Majelis Ulama Indonesia (MUI) sebagai lembaga pelaksana pemeriksaan pangan yang dinyatakan halal dan dikemas untuk diperdagangkan. Selain itu, melalui SK Nomor 525 Tahun 2001, Menteri Agama juga menunjuk Perum Percetakan Uang Republik Indonesia (Peruri) untuk mencetak label halal yang nantinya akan diberikan kepada produk yang sudah dinyatakan halal oleh MUI. ${ }^{51}$

Sertifikat halal yang dikeluarkan oleh MUI adalah milik MUI. Oleh sebab itu jika karena sesuatu hal diminta kembali oleh MUI maka pemegang sertifikat, dalam hal ini produsen, wajib untuk menyerahkannya.

\section{Penutup}

Sertifikasi halal menjadi kewajiban negara untuk memproteksi hak-hak konsumen Muslim dari mengkonsumsi makanan, obat-obatan dan kosmetika yang berasal dari jenis dan zat yang haram. Oleh karena itu perlu regulasi yang lebih jauh dan tegas untuk dapat menjangkau hak-hak konsumen Muslim. Hal ini urgen untuk dilakukan mengingat tidak semua umat Muslim paham bahwa apa yang mereka konsumsi belumlah halal menurut hukum syariat.

Disamping itu perlu juga untuk memberikan pemahaman, penegasan serta pengetahuan terhadap produsen untuk menjaga hak-hak konsumen Muslim. Sebagai negara dengan basis umat Islam terbesar di dunia sudah selaiknya para produsen lebih mementingkan tercapainya keamanan dan kenyamanan terhadap konsumen Muslim. Hal yang paling penting untuk diketahui bagi para produsen adalah bahwa sertifikasi dan labelisasi halal bukan hanya untuk keamanan bagi konsumen Muslim, melainkan juga memberikan keuntungan ekonomis bagi produsen. Sertifikasi dan labelisasi halal merupakan etika bisnis yang harus dijalankan oleh para produsen untuk melindungi hakhak kaum Muslim di Indonesia. []

\section{Pustaka Acuan}

\section{Buku/Jurnal:}

A. Mustofa, Akhlak Tasawuf, Bandung: Pustaka Setia, 1997.

Departemen Agama Republik Indonesia, Panduan Sertifikasi Halal, Jakarta: Departemen Agama RI, 2003.

Departemen Agama RI, Bunga Rampai Jaminan Produk Halal di Negara Anggota MABIMAS, Jakarta: Bagian Proyek Sarana dan Prasarana Produk Halal

\footnotetext{
${ }^{51}$ Mazhida, "Label Halal dan Ikhtiar Perlindungan Konsumen", dalam www.mazhida.wordpress.com, diunduh tanggal 11 Maret 2009.
}

Direktorat Jenderal Bimbingan Masyarakat Islam dan Penyelenggaraan Ibadah Haji Departemen Agama R.I., 2003.

Gazalba, Sidi, Sistematika Filsafat, Buku Keempat Pengantar kepada Teori Nilai, Jakarta: Bulan Bintang, 2002.

Hakim, Lukmanul, Labelisasi Halal sebagai Wujud Perlindungan Konsumen, Makalah, Jakarta: Lembaga Pengkajian Pangan, Obat-obatan dan Kosmetika Majelis Ulama Indonesia, 2004.

Hidayat, Mohamad, An Intoduction The Sharia Economic Pengantar Ekonomi Syariah, Jakarta: Zikrul Hakim, 2010.

Keraf, A. Sony, Etika Bisnis Tuntutan dan Relevansinya, Yogyakarta: Kanisius, 2005, Cet.VIII.

Ma'luf, Louis, Lisân al-Arab, Bayrût: al-Maktabah alKulliyah, t.th.

Muhaimin, et.al., Kawasan dan Wawasan Studi Islam, Jakarta: Prenada Media, 2005.

Mujahidin, Akhmad. "Etika Bisnis Dalam Islam (Analisis terhadap Aspek Moralitas Pelaku Bisnis)", dalam Majalah Hukum Islam, Vol. IV, No. 2 Desember 2005.

Qaradhawi, Yusuf, Norma dan Etika Ekonomi Islam, Jakarta: Gema Insani Press, 1997.

Rivai, Veithzal dan Andi Buchari, Islamic Economics Ekonomi Syariah Bukan OPSI, Tetapi SOLUSI!, Jakarta: Bumi Aksara, 2009.

Rivai, Veithzal, Amiur Nuruddin, Faisar Ananda Arfa, Islamic Business And Economics Ethics Mengacu pada Al-Qur'an dan Mengikuti Jejak Rasulullah Saw. dalam Bisnis, Keuangan dan Ekonomi, Jakarta: PT Bumi Aksara, 2012.

Siagiaan, Sondang P., Etika Bisnis, Jakarta: Pustaka Binaman Pressindo, 1996.

Siddiqi, Nejatullah, Kemitraan Usaha dan Bagi Hasil dalam Hukum Islam, Jakarta: Dana Bakti Prima Yasa, 1996.

Suseno, Frans Magnis, Etika Dasar: Masalah Pokok Filsafat Moral, Yogyakarta: Kanisius, 1991, Cet. III.

Syahathah, Husayn, Shiddîq Muhammad al-Amîn al-Dhâhir, Transaksi dan Etika Bisnis Islam. Terjemahan dari Business Ethics in Islam \& al-Gharar fî al-'Uqûd wa Atsâruhâ fî al-Thathbîq al-Mu'ashirah, penterjemah Saptomo Budi Satryo dan Fauziah, Jakarta: Visi Insani Publishing, 2005.

Tanjung, Mara Gandhi Prataman, Penerapan Etika Bisnis Islam sebagai Perlindungan Konsumen pada Penjualan Makanan Berlabel Halal, Skripsi, Medan: Fakultas Hukum Universitas Muhammadiyah Sumatera Utara, 2009.

Tarigan, Azhari Akmal, "Riba Dalam Al-Quran”, dalam 
Harian Waspada, edisi Jumat, 2 Januari 2004.

Thaib, Ismail, Risalah Akhlaq, Yogyakarta:CV.Bina Usaha, 1984.

Usman, Suparman, Hukum Islam Asas-Asas dan Pengantar Studi Hukum Islam dalam Tata Hukum Indonesia, Jakarta: Gaya Media Pratama, 2001.

Yusanto, M.Ismail dan M.Karebet Widjajakusuma, Menggagas Bisnis Islami, Jakarta: Gema Insani Press, 2002.

\section{Website:}

"Apa Itu Makanan Halal...??, dalam www.zona-sosial. blogspot.com, diunduh tanggal 17 Maret 2013.

"Pentingnya Sertifikasi Halal untuk Produk Makanan Indonesia (Halal Sertification Acquire For Indonesian Food)", dalam www.duniailmupeternakan.blogspot. com, diunduh tanggal 14 Maret 2013.

"Perlu Aturan yang Wajibkan Pengusaha Cantumkan Label Halal", dalam www.jurnal-ekonomi.org, diunduh tanggal 11 Februari 2009.

Apriyantono, "Penentuan Kehalalan Produk Pangan
Hasil Bioteknologi: Suatu Tantangan”, dalam www. indohalal.com., diunduh tanggal 11 Februari 2009.

As Syifa Hanif, "Urgensi Sertifikasi Halal", dalam www. coretanhanifah.wordpress.com., diunduh tanggal 17 Maret 2013.

Fokky, "Perlindungan Konsumen Pangan dalam Perspektif Islam", dalam www.uai.ac.id., diunduh tanggal 10 Maret 2009.

Hasan,"Label Halal”, dalam www.hasan.sayanginanda. com, diunduh tanggal 11 Februari 2009.

Mazhida, "Label Halal dan Ikhtiar Perlindungan Konsumen", dalam www.mazhida.wordpress.com, diunduh tanggal 11 Maret 2009.

Muchtar, Moh. Anas, "Pentingnya Sertifikasi Halal Melalui LPPOM dan MUI", dalam www. madinatualim.com, diunduh pada tanggal 17 Maret 2013.

Suryadhie, "Etika Perdagangan Islam", dalam www. suryadhie/wordpress.com, diunduh tanggal 13 Maret 2012. 